\title{
KORELASI UMUR DENGAN KADAR HEMATOKRIT, JUMLAH LEUKOSIT, DAN TROMBOSIT PASIEN INFEKSI VIRUS DENGUE
}

\author{
THE CORRELATION BETWEEN AGE WITH HEMATOCRIT, LEUKOCYTE, AND \\ PLATELETS COUNTS OF DENGUE VIRUS INFECTION PATIENTS
}

\author{
Safari Wahyu Jatmiko \\ Departemen Patologi Klinik Fakultas Kedokteran Universitas Muhammadiyah Surakarta \\ Korespondensi: dr. Safari Wahyu Jatmiko, M. Si.Med. Email: safari.wahyu@ums.ac.id
}

\begin{abstract}
ABSTRAK
Infeksi virus dengue (IVD) masih menjadi masalah di negara tropis dan sub tropis. Gejala IVD dan perubahan parameter hematologi seperti jumlah leukosit, trombosit dan kadar hematokrit. pada umumnya lebih berat pada pasien infeksi sekunder dengue virus (DENV) dengan serotipe yang berbeda. Risiko infeksi sekunder DENV meningkat seiring dengan bertambahnya usia. Hal ini menimbulkan landasan teori terhadap hipotesis bahwa semakin bertambah usia maka perubahan parameter hematologi semakin berat. Untuk menjawab hal tersebut dilakukan penelitian terhadap pasien IVD yang berusia dibawah 14 tahun dan memenuhi kriteria diagnostik WHO 2009. Diagnosis dikonfirmasi dengan $\operatorname{Ig} G$ dan $\operatorname{Ig} M$ antidengue. Hasil yang didapat adalah terdapat korelasi antara usia dengan kadar hematokrit dengan $r=0,248$ dan $p=0,027$ namun tidak ada korelasi antara usia dengan jumlah leukosit dengan $r=0,008 p=0,943$ dan trombosit dengan $r-0,01 p=0,929$. Semakin bertambah usia maka semakin berat peningkatan kadar hematokrit pada anak penderita IVD.
\end{abstract}

Kata kunci: Umur, Hematokrit, Leukosit, Trombosit, Infeksi Virus Dengue

ABSTRACT

Dengue virus infection (IVD) is still a problem in tropical and sub-tropical countries. Symptoms of IVD and changes in hematological parameters such as the number of leukocytes, platelets and hematocrit levels are generally more severe in secondary DENV infections with different serotypes. The risk of secondary DENV infection increases with age. This raises the theoretical basis of the hypothesis that the older the worsening changes in hematologic parameters. To address this, a study of IVD patients under 14 years old and meeting the 2009 WHO diagnostic criteria is done. The diagnosis is confirmed by $\operatorname{Ig} G$ and $\operatorname{IgM}$ antidengue. The result are correlation between age with hematocrit level with $r=0,248$ and $p=0,027$ but no correlation between age with leukocyte count with $r=0,008 p=0,943$ and platelet with $r-0,01 p=0,929$. It can be concluded that the more aged the more severe the increase in hematocrit levels in children with IVD.

\section{Keywords: Age, Hematocrit, Leukocyte, Platelet, Dengue Virus Infection}

\section{PENDAHULUAN}

Infeksi virus dengue (IVD) merupakan penyakit arbovirus yang utama dan banyak ditemukan di daerah tropis dan sub tropis (Guo et al., 2017; Malavige et al., 2011). Dilaporkan bahwa insiden IVD secara global sebanyak 58,4 juta pada tahun 2013 dengan rata-rata angka kematian 9.221 per tahun (Stanaway et al., 2016). Data penelitian yang dilakukan di Indonesia menunjukkan bahwa insiden IVD adalah 35-40 / 100.000 penduduk dengan kasus terbanyak terjadi di propinsi Jawa Barat (Karyanti et al., 2014; Kosasih et al., 2016).
Sebagian besar kasus IVD tidak menimbulkan gejala, akan tetapi 57,8\% dari semua pasien IVD yang bergejala dilaporkan mencari pengobatan dan 183.297 kasus memerlukan rawat inap (Wahyono et al., 2017). Gejala dan tanda IVD bervariasi, mulai dari yang ringan (seperti demam, mialgia, sakit kepala, dan muntah) sampai gejala yang berat dan mengancam jiwa (Jakribettu et al., 2015). Gejala dan tanda IVD diikuti dengan perubahan parameter laboratorium hematologi seperti trombositopenia, leukopenia, dan hemokonsentrasi (Ghazali et al., 2013; Khandelwal \& Khandelwal, 2017; Tsai et al., 
2017). Perubahan parameter tersebut memburuk seiring dengan beratnya IVD (Joshi et al., 2017; Simmons et al., 2015). Meskipun pendapat ini ditentang oleh peneliti yang lain karena tidak adanya hubungan yang bermakna antara IVD dengan derajad trombositopenia dan peningkatan hematokrit (Wiwanitkit \& Manusvanich, 2004).

Bentuk IVD berat terkait dengan infeksi virus dengue (DENV) berulang dengan serotipe yang berbeda(Diamond \& Pierson, 2015; Halstead, 2015). Kejadian infeksi berulang meningkat seiring dengan bertambahnya usia (Kuo et al., 2017; Thai et al., 2011). Hasil penelitian menunjukkan bahwa insiden IVD terbanyak pada anak usia sekolah lebih dari 7 tahun serta adanya kecenderungan bahwa insiden IVD beralih ke pasien dengan umur yang lebih tua (Karyanti et al., 2017; Pan et al., 2014). Usia yang lebih tua meningkatkan risiko infeksi sekunder oleh serotipe DENV yang berbeda. de Souza et al. (2013) melaporkan bahwa derajad trombositopenia, leukopenia, dan peningkatan hematokrit lebih berat pada orang dewasa daripada anak-anak. Penelitian Khurram et al. (2014) menunjukkan bahwa derajad trombositopenia dan peningkatan kadar ALT lebih berat pada pasien dengan infeksi sekunder serotipe DENV yang berbeda. Hingga saat ini masih terdapat perdebatan mengenai hubungan antara kejadian IVD berat dengan reinfeksi sekunder dengan serotipe DENV yang berbeda. Halstead (2012) meragukan teori tersebut karena adanya fakta bahwa teori infeksi sekunder dibangun dari hasil pemeriksaan serologis yang dilakukan satu kali saat fase akut dan adanya faktor lain yang terlibat dalam terjadinya IVD berat.

Fakta menunjukkan bahwa semakin bertambah usia semakin berisiko terkena IVD berat. Ketika terjadi IVD berat maka derajad trombositopenia, hemokonsentrasi, dan leukopenia juga semakin memburuk. Pada saat yang sama diyakini bahwa banyak faktor yang berpengaruh terhadap kejadian IVD serta masih ada hasil penelitian yang gagal membuktikan bahwa semakin berat IVD akan menyebabkan memburuknya parameter hematologi. Berdsarakan hal tersebut maka penulis ingin mengetahui apakah perubahan parameter hematologi seperti jumlah trombosit, leukosit, dan hematokrit pasien IVD dipengaruhi oleh usia pasien.

\section{METODE}

Desain penelitian menggunakan analitik korelasi dengan pendekatan cross sectional. Penelitian dilakukan di RS X Surakarta dari bulan September 2016 - Januari 2017. Data diambil dari pasien anak yang menjalani rawat inap dengan kriteria inklusi : usia kurang dari 14 tahun, memenuhi kriteria IVD menurut WHO 2009, dan diagnosis terkonfirmasi dengan pemeriksaan IgG dan IgM anti dengue. Pasien dengan riwayat kelainan hematologi dikeluarkan dari penelitian. Sampel penelitian diambil menggunakan cara consecutive sampling.

Pemeriksaan hitung trombosit, leukosit, dan hematokrit dilakukan di Laboratorium RS XSurakarta, sedangkan pemeriksaan tes serologis dilakukan di Laboratorium Patologi Klinik Fakultas Kedokteran Universitas Muhammadiyah Surakarta. Sampel menggunakan darah vena dengan antikoagulan k3EDTA. Hitung trombosit, leukosit, dan hematokrit diperiksa menggunakan hematology analyzer Sysmex sedangkan antibodi antidengue menggunakan rapid dengue test (Mono IgM-IgG Tri Line Test). Pemeriksaan laboratorium mengacu kepada petunjuk penggunaan alat dari produsen.

Data yang didapat dilakukan uji normalitas data menggunakan Kolmogorov-smirnov. Hipotesis diuji menggunakan uji analisis korelasi dengan bantuan software statistik.

\section{HASIL DAN PEMBAHASAN}

Selama penelitian didapatkan 95 pasien. Sebanyak 15 pasien dikeluarkan dari penelitian karena tidak terkonfirmasi secara serologis, sehingga hanya 80 pasien yang terlibat di dalam penelitian. Deskripsi pasien disajikan pada tabel 1, sedangkan hasil uji korelasi antara umur dengan hematokrit, trombosit, dan leukosit dapat dilihat pada tabel 2 . 
Tabel 1. Hasil penelitian

\begin{tabular}{lcc}
\hline \multicolumn{1}{c}{ Parameter } & Mean (SD) & $\begin{array}{c}\text { Median } \\
\text { (minimal-maksimal) }\end{array}$ \\
\hline Usia (Tahun) & - & $8,5(0,3-13)^{\#}$ \\
Leukosit $\left(10^{3} / \mathrm{mm}^{3}\right)$ & $5,47(2,46)^{*}$ & - \\
Hematokrit $(\%)$ & - & $37(30-55)^{\#}$ \\
Trombosit $\left(10^{3} / \mathrm{mm}^{3}\right)$ & - & $65,5(12-223)^{\#}$ \\
\hline \multicolumn{1}{c}{ Keterangan : ${ }^{*}$ Uji kolmogorov-smirnov $\mathrm{p}>0,05, \#$ Uji kolmogorov-smirnov $\mathrm{p}<0,05$}
\end{tabular}

Tabel 2. Hasil Korelasi Umur Dengan Hematokrit, Trombosit, Dan Leukosit

\begin{tabular}{ccccc}
\hline & & Leukosit $^{*}$ & Hematokrit $^{\#}$ & Trombosit $^{\#}$ \\
\hline \multirow{2}{*}{ Usia } & $\mathrm{r}$ & 0,008 & 0,248 & $-0,01$ \\
& $\mathrm{p}$ & 0,943 & 0,027 & 0,929 \\
& $\mathrm{n}$ & 80 & 80 & 80 \\
\hline \multirow{2}{*}{ Keterangan : * Pearson corellation, \# Spearman Rank Correlation Coefficient }
\end{tabular}

Pada penelitian didapatkan bahwa usia pasien IVD adalah 8,5 (0,3-13) tahun. Hasil ini tidak berbeda dengan penelitian-penelitian lain yang menunjukkan bahwa pasien IVD lebih sering mengenai anak usia sekolah ( 7 - 14 tahun) yang biasanya lebih berisiko sering kontak dengan vektor (Jatmiko, 2017; Jatmiko et al., 2017; Pan et al., 2014).

Jumlah leukosit pada penelitian adalah $5,47(2,46) \times 10^{3} / \mathrm{mm}^{3}$ yang menunjukkan tidak ditemukannya leukopenia pada subyek penelitian. Hasil ini sejalan dengan penelitian terdahulu bahwa jumlah leukosit pasien IVD berada pada kisaran nilai rujukan (Jakribettu et al., 2015; Khandelwal \& Khandelwal, 2017). Hitung leukosit yang normal disebabkan karena perjalanan penyakit yang belum lama (demam subyek penelitian ratarata 4 hari) dan derajad penyakit yang belum berat. Telah diketahui bahwa leukopenia akibat supresi sumsum tulang terjadi pada pasien IVD yang berat dan ketika infeksi telah berlangsung lama mendekati fase penyembuhan (Azin et al., 2012; Hartoyo, 2008). Disamping itu, hanya sekitar $40 \%$ leukopenia yang terdeteksi bersamaan dengan saat diagnosis (Krishnamurthy, et al., 2016). Alasanalasan tersebut juga mendasari hasil uji analisis korelasi antara usia dengan jumlah leukosit yang menunjukkan korelasi sangat lemah dan tidak signifikan.

Tabel 1 menunjukkan bahwa jumlah trombosit pasien IVD adalah 65,5 (12-223) $\times 10^{3 /}$ $\mathrm{mm}^{3}$. Hasil ini sejalan dengan penelitian terdahulu yang memberikan bukti bahwa trombositopenia merupakan kelainan parameter hematologi yang selalu ditemui pada pasien IVD (Bashir et al., 2015, Jatmiko, 2017). Tabel 2 memberikan informasi bahwa hasil uji analisis korelasi antara usia dengan jumlah trombosit menunjukkan korelasi sangat lemah dan tidak signifikan. Hal ini terjadi karena banyak hal yang mempengaruhi terjadinya trombositopenia pada pasien IVD, diantaranya adalah supresi sumsum tulang, sekuestrasi trombosit, infeksi megakariosit, pengrusakan trombosit karena adanya autoantibodi antiplatelet, dan apoptosis trombosit (Jatmiko, 2016). Interaksi antara faktor-faktor tersebut beserta penggunaan antikoagulan K3EDTA bisa jadi menyebabkan tidak adanya korelasi antara usia dengan jumlah trombosit. Antikoagulan K3EDTA diketahui bisa menimbulkan terjadinya clumping trombosit, sehingga bisa menyebabkan hasil penghitungan trombosit yang jauh di bawah dari nilai sesungguhnya (Fang et al., 2015).

Pada penelitian ini didapatkan bahwa kadar hematokrit pasien IVD adalah 37 (30-55)\%. Hasil hematokrit di atas $36,3 \%$ pada pasien IVD patut dicurigai akan adanya hemokonsentrasi yang biasanya terjadi sebelum pasien jatuh ke dalam sindrom syok dengue (Gomber et al., 2001; Yacoub \& Wills, 2014). Hemokonsentrasi pada pasien IVD selalu dikaitkan dengan kebocoran vaskuler (Joshi et al., 2018). Telah dibuktikan bahwa kebocoran vaskuler terjadi karena adanya badai sitokin yang berkorelasi positif dengan infeksi sekunder DENV dari serotipe yang berbeda (Cardozo et al., 2017; Her et al., 2017). Pada tabel 2 didapatkan bahwa terdapat korelasi lemah dan bermakna secara statistik antara usia dengan kadar hematokrit. Hasil ini terjadi karena semakin bertambah usia maka risiko terkena infeksi sekunder DENV dengan 
serotipe berbeda semakin meningkat, sehingga infeksi sekunder tersebut meningkatkan terjadinya kebocoran plasma. Hasil penelitian meskipun membuktikan adanya korelasi antara usia dengan kadar hematokrit, akan tetapi derajad korelasinya lemah. Hal ini terjadi karena adanya intervensi pemberian cairan intravena sebelum pemeriksaan hematokrit dikerjakan, sehingga hemokonsentrasi tidak terlalu berat yang mengakibatkan kadar hematokrit menjadi berkurang (Fujimoto \& Koifman, 2014).

Terdapat beberapa keterbatasan di dalam penelitian kami. Diantara keterbatasan tersebut adalah tidak dikelompokkannya parameter hematologi berdasarkan usia, pengambilan data hanya satu kali, dan adanya intervensi pemberian cairan intravena pada semua subyek penelitian sebelum data diambil.

\section{SIMPULAN DAN SARAN}

Dari penelitian yang telah dilakukan menunjukkan bahwa semakin bertambah usia semakin berat hemokonsentrasi yang terjadi namun usia tidak berkorelasi dengan jumlah trombosit dan leukosit.

Berdasarkan keterbatasan penelitian yang ada maka perlu dilakukan penelitian serupa dengan menggunakan pengelompokan parameter hematologi berdasarkan usia, pengambilan data sebelum dilakukan intervensi cairan intravena, dan data parameter hematologi diambil secara serial.

\section{DAFTAR PUSTAKA}

Azin, F.R.F.G., Gonçalves R.P., Pitombeira M.H.D., Lima D.M., Branco I.C., 2012. Dengue: profile of hematological and biochemical dynamics. Rev Bras Hematol Hemoter.34(1):36-41

Bashir, A.B., Mohammed, B.A., Saeed, O.K., and Ageep, A.K. 2015. Thrombocytopenia and Bleeding Manifestation among Patient with Dengue Virus Infection in Port Sudan, Red Sea State of Sudan. J Infect Dis Immun. 7(2):7-13

Cardozo, F. T. G. D. S., Baimukanova G., Lanteri M. C., Keating S.M., Moraes, F., Heitman, J., et al. 2017. Serum from dengue virus-infected patients with and without plasma leakage differentially affects endothelial cells barrier function in vitro. PLOS ONE, 12(6): e0178820.

de Souzaa, L. J., Pessanha, L. B., Mansur, L. C., de Souzaa, L. A., Ribeiro, M. B. T., da Silveira, M. D. V., et al., 2013. Comparison of clinical and laboratory characteristics between children and adults with dengue. Braz J Infect Dis. 17;(1):27-31

Diamond, M. S., and Pierson, T. C., 2015. Molecular Insight into Dengue Virus Pathogenesis and Its Implications for Disease Control. Cell. 162: 488-92

Fang, C. H., Chien, Y. L., Yang, L. M.., Lu, W. J., Lin, M. F., 2015. EDTA-dependent pseudothrombocytopenia. Formosan J of Surg. 48:107-9

Fujimoto, D. E., and Koifman, S., 2014. Clinical and laboratory characteristics of patients with dengue hemorrhagic fever manifestations and their transfusion profile. Rev Bras Hematol Hemoter.36(2):115-20

Ghazali, M. N. B. M., Intansari, U. S., dan Laksanawati, I. S., 2013. The Kinetics of White Blood Cells in Acute Dengue Infection. Trop Med J, 03;(1): 29-38

Gomber, S., Ramachandran, V.G., Kumar, S., Agarwal, K.N., Gupta, P., Gupta, P. et al. 2001. Hematological Observations as Diagnostic Markers in Dengue Hemorrhagic Fever - A Reappraisal. Indian Pediatric. 38:477-81

Guo, C., Zhou, Z., Wen, Z., Liu, Y., Zeng, C., Xiao, D., Ou, M., Han, Y., Huang, S., Liu, D., Ye, X., Zou, X., Wu, J., Wang, H., Zeng, E.Y., Jing, C. and Yang, G., 2017. Global Epidemiology of Dengue Outbreaks in 1990-2015: A Systematic Review and Meta-Analysis. Front. Cell. Infect. Microbiol. 7;(317):1-11

Halstead, S. B., 2012. Controversies in dengue pathogenesis. Paed Int Child Health, 32;(sup1):5-9 
Halstead, S. B., 2015. Pathogenesis of Dengue: Dawn of a New Era. F1000Research. 4;(F1000 Faculty Rev):1353

Hartoyo, E. 2008. Spektrum Klinis Demam Berdarah Dengue pada anak. Sari Pediatri, 10(3):145-50

Her, hisheng., Kam, Y. W., Gan, V. C., Lee, B., Thein, T. L., Tan, J. J. L., et al., 2017. Severity of Plasma Leakage Is Associated With High Levels of Interferon $\gamma$-Inducible Protein 10, Hepatocyte Growth Factor, Matrix Metalloproteinase 2 (MMP-2), and MMP-9 During Dengue Virus Infection. $J$ Infect Dis, 215:42-51

Jakribettu, R. P., Boloor, R., Thaliath, A., George, S. Y., George, T., Rai, M. P., et al., 2015. Correlation of Clinicohaematological Parameters in Paediatric Dengue: A Retrospective Study. J Trop Med. 647162:1-7

Jatmiko, S.W. 2016. Hubungan Kadar Rheumatoid Factor dengan Perubahan Jumlah Trombosit dan Nilai Hematokrit pada Anak Terinfeksi Virus Dengue. Semarang: Universitas Diponegoro (Thesis). 1-58

Jatmiko, SW. 2017. Status Serologis Tidak Mempengaruhi Profil Hematologi Anak Terinfeksi Virus Dengue. Biomedika, 9;(1):50-4

Jatmiko, S.W., Suromo, L., Dharmana, E., 2017. IgM-RF pada Anak Terinfeksi Virus Dengue Tidak Berkorelasi dengan Jumlah Trombosit dan Hematokrit. JKB, 29;(4):306-11

Joshi AA, Divyashree BN, Gayathri BR. 2018. The Hematocrit Spectrum in Dengue. Int J Sci Stud;5(10):1-5

Joshi, Anagha A., Gayathri B. R., Gowda R, Yashica., 2017. The total leucocyte count: its utility in dengue. Int $J$ Adv Med.4;(6):1621-6

Karyanti, M. R., Uiterwaal, C. S. P. M., Kusriastuti, R., Hadinegoro, S. R., Rovers, M. M., Heesterbeek, H., Hoes, A. W., Bruijning-Verhagen, P., 2014. The changing incidence of Dengue Haemorrhagic Fever in Indonesia: a 45-year registry-based analysis.

BMC Infect Dis, 14:412

Khandelwal, R., Khandelwal, L.M., 2017. Effect of dengue fever on the total leucocyte count and neutrophil count in children in early febrile period. Int J Ped Res, 4;(10): 617-22

Kosasih, H., Alisjahbana, B., Nurhayati , de Mast, Q., Rudiman, I.F., Widjaja, S., et al. 2016. The Epidemiology, Virology and Clinical Findings of Dengue Virus Infections in a Cohort of Indonesian Adults in Western Java. PLoS Negl Trop Dis. 10;(2): e0004390.

Krishnamurthy, V., Rajashekar, R., Doreswamy, S. M., 2016. Peripheral cell line suppression in dengue infection in relation to serological status. Asian Journal of Medical Sciences. 7(5):

Kuo, H. J., Lee, I. K., Liu, J. W., 2017. Analyses of clinical and laboratory characteristics of dengue adults at their hospital presentations based on the World Health Organization clinical-phase framework: Emphasizing risk of severe dengue in the elderly, J Microbiol Immunol Infect. article in press

Khurram, M., Qayyum, W., Hassan, S. J., Mumtaz, S., Bushra, H. T., Umar, M., 2014. Dengue hemorrhagic fever: Comparison of patients with primary and secondary infections. J Infect Public Health. 7:489-95

Malavige, G. N., Fernando, N., Ogg, G., 2011. Pathogenesis of Dengue viral infections. Sri Lankan J Infect Dis.1;(1): 2-8

Pan, S. T, Su, P. A., Chen, K. T.., Lin, H. J., Lai, W. P., 2014. Comparison of the clinical manifestations exhibited by dengue and nondengue patients among children in a medical center in southern Taiwan. $J$ Acute Med. 4:53-6

Simmons, C. P., McPherson, K., Chau, N.V. V., Tame, D.T. H., Young, P., Mackenzie, J., et al., 2015. Recent advances in dengue pathogenesis and clinical management. Vaccine. 33:7061-8 
Stanaway, J. D., Shepard, D. S., Undurraga, E. A., Halasa, Y. A., Coffeng, L. E., Brady, O. J., Hay, S. I. Bedi, N., Bensenor, I. M., Castañeda-Orjuela, C. A., et al., 2016. The Global Burden of Dengue: an analysis from the Global Burden of Disease Study 2013. Lancet Infect Dis. 16;(6):712-23

Thai, K.T.D., Nishiura, H., Hoang, P.L., Tran, N.T.T., Phan, G.T., Le, H.Q., et al. 2011 Age-Specificity of Clinical Dengue during Primary and Secondary Infections. PLoS Negl Trop Dis, 5;(6):e1180.

Tsai, J. J., Chang, J. S., Chang, K., Chen, P. C., Liu, L. T., Ho, T. C, et al., 2017. Transient Monocytosis Subjugates Low Platelet Count in Adult Dengue Patients. Biomed Hub, 2;(457785):1-16

Wahyono, T. Y. M., Nealon, J., Beucher, S., Prayitno, A., Moureau, A., Nawawi, S., Thabrany, H., Nadjib, M., 2017. Indonesian dengue burden estimates: review of evidence by an expert panel. Epidemiol. Infect. 145:2324-9

Wiwanitkit, V, and Manusvanich, P. 2004. Can hematocrit and platelet determination on admission predict shock in hospitalized children with dengue hemorrhagic fever? A clinical observation from a small outbreak. Clin Appl Thromb Hemost. 10(1):65-7

Yacoub, S. and Wills, B., 2014. Predicting outcome from dengue. BMC Med, 12(147):1-10 